\title{
Using an Technology Readiness Model to Understand Perceived Usefulness of Learning in the Covid-19 Era
}

\author{
Gestiardi $^{*}$, Sarwanto $^{2}$, Chumdari ${ }^{3}$, Maryani ${ }^{4}$ \\ 1,2,3 Graduate Program, Faculty of Teacher Training and Education, Universitas Sebelas Maret, Surakarta, Indonesia \\ ${ }^{4}$ Faculty of Teacher Training and Education, Universitas Ahmad Dahlan, Yogyakarta, Indonesia
}

\section{ART I CLE IN F O}

\section{Article history:}

Received September 04, 2021

Revised September 08, 2021

Accepted October 28, 2021

Available online November 25, 2021

\section{Kata Kunci:}

Pendidikan Agama Islam,

Komunikasi, Motivasi

\section{Keywords:}

Islamic Religious Education,

Communication, Motivation

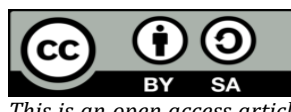

This is an open access article under the $C C$ BY-SA license.

Copyright (C) 2021 by Author. Published by Universitas Pendidikan Ganesha.

\begin{abstract}
A B S T RA K
Penggunaan teknologi baru bagi pendidik menyulitkan pendidik untuk memperbarui pembelajaran yang ada, keterampilan pengetahuan, dan berbagai pengetahuan, namun penerapan teknologi hingga sikap pendidik dalam mengadopsi teknologi baru ditambah dengan pandemi covid-19 yang mengharuskan pendidik menyiapkan teknologi. Kesiapan teknologi (TR) menjadi model dalam mempersiapkan teknologi yang menjadi ciri khas individu dalam penggunaan dan adaptasi teknologi baru untuk mencapai tujuan yang diinginkan. Perceived usefulness menjadi sebuah indikator penting terhadap sikap yang kita ambil dalam penggunaan teknologi tertentu. Tujuan penelitian ini adalah menganalisis TR terhadap perceived usefulness dalam pembelajaran di era Covid19. Penelitian ini berfokus pada memberikan pemahaman dan kesadaran umum akan pentingnya TR dalam kehidupan sehari-hari. Jenis penelitian ini adalah kuantitatif dengan menggunakan analisis unvariate dan regresi linear sederhana. Desain penelitian ini termasuk penelitian korelasional. jumlah sampel 215 mahasiswa yang terlibat. Alat pengumpulan datanya menggunakan kuesioner online. Hasilnya ialah mahasiswa pendidikan guru sekolah di Yogyakarta memiliki kemampuan TR yang tinggi dan mempengaruhi efek positif terhadap perceived usefulness. Penelitian ini menyiratkan bahwa pendidik atau seluruh pemangku kepentingan menyadari pentingnya TR dan penggunaan layanan teknologi dengan mendorong penggunaan sikap positif terhadap teknologi untuk mengurangi keengganan menggunakan teknologi.
\end{abstract}

\section{A B S T R A C T}

The use of new technology for educators makes it difficult for educators to update existing learning, knowledge skills, and various knowledge. However, the application of technology to the attitude of educators in adopting new technology is joined with the covid-19 pandemic, which requires educators to prepare technology. Technology readiness (TR) becomes a model in preparing technology that characterizes individuals using and adopting new technologies to achieve the desired goals. Perceived usefulness is an essential indicator of the attitude we take in the use of specific technologies. The purpose of this study was to analyze the TR of perceived usefulness in learning in the Covid-19 era. This research focuses on providing a general understanding and awareness of the importance of TR in everyday life. This type of research is quantitative, using univariate analysis and simple linear regression. This research design includes correlational research. The number of samples was 215 students were involved. The data collection tool uses an online questionnaire. The result is that school teacher education students in Yogyakarta have high TR abilities and positively affect perceived usefulness. This research implies that educators or stakeholders realize the importance of TR and technology services by encouraging positive attitudes towards technology to reduce reluctance to use technology.

\section{INTRODUCTION}

The use of technology has proliferated to reach 7 billion or $95 \%$ of the world's population. Technology also affects the economic, sociological, and psychological aspects of rapid technological growth (Blakely et al., 2020; MacLachlan et al., 2018; Summak et al., 2010). The use of technology is very important because it can increase efficiency and effectiveness in every use sector (Al-Hariri \& Al-Hattami, 2017; Burbules et al., 2020; Winter et al., 2021) . In the world of education, the effect has been seen positively in teaching, learning, research, and information to students (Haidari et al., 2019). Technology has played an essential role in improving the quality of education that has been incorporated into the education system (Winter et al., 2021). Educational integration provides exploration and enables it as an essential means of realizing the Sustainable Development Goals (SDGs) in education (Christopoulos \& Sprangers, 2021; Rafiee \& Abbasian-Naghneh, 2021; Unwin, 2019). This means that technology is able to improve results in learning and has an important role (Liu \& Wang, 2020). 
Indonesia is one of the countries that have adopted and followed rapid technological advances (Aini et al., 2020; Rahardja et al., 2019; Saddhono et al., 2019). However, this progress is not accumulated up by Human Resources (HR), who can keep up with changes in world education. Often we find that educators maintain traditional ways of delivering the learning process and are still reluctant to use technology. Educational technology choices make it difficult for educators to constantly update their knowledge, skills, and information from multiple sources and exacerbate educational inequalities (Tuma, 2021; Warden et al., 2020). Many developing countries, including Indonesia, cannot use the potential competitive advantage of technology, especially in education (Alam \& Asimiran, 2021; Shohel \& Kirkwood, 2012). These problems are examples of problems and challenges for students as aspiring future teachers ready for technologybased education. Prospective teachers are required to understand the concept of the times in order to be able to realize the progress of a nation, especially in the world of education (Burbules et al., 2020; Danniels et al., 2020).

The Covid-19 virus has become a new challenge, especially in the education sector, which is happening almost all over the world (Bozkurt et al., 2020; Christopoulos \& Sprangers, 2021; Lau \& Lee, 2021). But individuals must rely on the ability to adapt both in thoughts, behaviors, and emotions to deal with rapidly changing situations (Howard et al., 2016; Saha et al., 2021). We all agree that educational technology has been around for a long time, but the technology before has not had enough of the expected impact. The pandemic forced all aspects to turn to digital tools to respond to these challenges, some individuals responded with positive behavior, and some things were detrimental (Mali \& Lim, 2021; Winter et al., 2021). This is due to students' inability to change technology, and students still tend to get used to face-to-face learning so that, if they come face to face with technology, it will have an impact on decreasing motivation and learning responsibilities. At the same time, technology provides a great perspective into the role of education in transforming the learning process, supporting continuous study, and facilitating students around the world during distance learning (Abbasi et al., 2020; Bozkurt et al., 2020).

One of the terms in preparing technology is Technology Readiness (TR), a concept developed to characterize the tendency of individuals to use and adapt new technologies to achieve goals both in work, tasks, and daily activities (Park \& Zhang, 2021; Richardson et al., 2021). The integration of technology into education can develop itself towards technology integration, which has been considered a determining factor in how well a prospective teacher can use technology effectively to improve teaching and learning (Al-Hariri \& Al-Hattami, 2017; Alam \& Asimiran, 2021). The use of technology is generally profitable but the key lies in its users (Martínez-Gautier et al., 2021). A teacher candidate's positive attitude helps teacher candidates use more instructional technology tools and makes learning more interesting for students. Prospective teachers who have a negative attitude and do not accept technology readiness are not required to use technology efficiently in integrating technology into education in teaching (Hoareau et al., 2021; Petko et al., 2018; Yilmaz \& Goktas, 2017). Practically the use of technology by prospective teachers can be a determinant of the effectiveness factor (Comi et al., 2017; Weng \& Chen, 2020).

The use of technology is always related to the perceived usefulness of how technology is practical in everyday life. Perceived usefulness is an essential indicator of the attitude we take in the use of a particular technology. Perceived usefulness has a strong relationship with other technology perceptions that affect technology adoption (Y.-Z. Chang et al., 2020; Zhu \& Luo, 2021). In addition, perceived usefulness notes the role of mediation in various aspects. Previous research has shown a large impact in exploring the positive relationship between perceived usefulness. The result is that if individuals can use technology, it will make it easier to find the information they want as well as an efficient and effective process (Chung et al., 2017; Kaushik \& Rahman, 2017; Martens et al., 2017; Roy et al., 2017). The individual's willingness to prepare for the use of technology (Bakirtaş \& Akkaș, 2020; Liao et al., 2018). The difference lies in the belief in the use of technology on academic staff, while this study focuses on describing the ability of prospective teacher technology readiness and its effect on perceived usefulness.

Given the importance of TR abilities in students, this needs to be analyzed to determine the big picture of students' TR abilities. The main objective of this study is to analyze and interpret how much influence TR has on perceived usefulness, This is in line with (Sun et al., 2020). The aim of this research is relevant to inform and correct potential deficiencies in students' TR abilities. The implications of the results of this study are required to increase knowledge about TR abilities and realize the importance of TR abilities in daily life.

\section{METHOD}

This research uses this type of quantitative research. This research is included in this type of correlation research because it focuses on knowing the relationship of two or more variables without making any changes. This research design uses survey design, a method commonly used in social research. 
In its use, survey design uses questionnaires for data collection that is distributed directly or online. This study uses a sample of Cohen and Marison's theory with a population of 1,100. The sample to be carried out in this study was 215 final semester students of primary school teacher education at Ahmad Dahlan University, with 70 males and 145 females involved and declared valid. Inaccurate samples will only lead to unexpected research conclusions or lead to misleading conclusions.

The data collection technique in this study used a questionnaire using a Likert scale of 1-5 with a score of disagreement as one and strongly agree to be given a 5. This study's TR indicators and perceived usefulness were equipment capability, technology skills, self-direct learning, motivation, and technology acceptance. The research instruments can be viewed in Tables 1 and Table 2 . The data generated in this study is in the form of quantitative data. The presentation of quantitative data was collected from online questionnaires, and then the data were analyzed using simple regression. The research results are then presented in tabular form and discussed in depth. The criteria for categorizing TR abilities are measured through the standard curve distribution of the criteria, and their aspects can be viewed in Table 3.

Table 1. Instrumen Technology Readiness

\begin{tabular}{|c|c|c|c|}
\hline Aspects & Indicators & $\begin{array}{l}\text { Statement } \\
\text { Item No }\end{array}$ & Sum \\
\hline $\begin{array}{l}\text { Kesiapan Perangkat } \\
\text { (Equipment } \\
\text { Capabilty) }\end{array}$ & $\begin{array}{l}\text { To find out the source of accessing } \\
\text { technology }\end{array}$ & $1,2,3,4,5$ & 5 \\
\hline Technology Skill & $\begin{array}{l}\text { Respond and know how level of } \\
\text { proficiency students in the use of } \\
\text { technology }\end{array}$ & $1,2,3,4,5,6,7,8,9,10,11,12$ & 12 \\
\hline \multirow[t]{2}{*}{ Self Direct Learning } & $\begin{array}{l}\text { Increase efforts as best as possible in } \\
\text { time management }\end{array}$ & $1,2,3,4,5,6,7$ & 7 \\
\hline & $\begin{array}{l}\text { Committed to boosting confidence and } \\
\text { believing in ability }\end{array}$ & $8,9,10,11,12,13,14$ & 7 \\
\hline Motivasi & $\begin{array}{l}\text { To find out the motivation in the use of } \\
\text { technology and the purpose of its use }\end{array}$ & $1,2,3,4,5$ & 5 \\
\hline \multicolumn{3}{|c|}{ Sum } & 36 \\
\hline
\end{tabular}

Table 2. Instrumen Perceived Usefulness

\begin{tabular}{cccc}
\hline Aspects & Indicators & $\begin{array}{c}\text { Statement } \\
\text { Item No }\end{array}$ & Sum \\
\hline $\begin{array}{c}\text { Kesiapan Perangkat } \\
\text { (Equipment } \\
\text { Capabilty) }\end{array}$ & $\begin{array}{l}\text { To find out the benefits of accessing } \\
\text { technology in online time }\end{array}$ & $1,2,3,4,5,6,7,8,9,10$ & 10 \\
\hline & Sum & & 10 \\
\hline
\end{tabular}

Table 3. Category Technology Readiness

\begin{tabular}{ccccc}
\hline Category & $\begin{array}{c}\text { Equipment } \\
\text { Capabilty }\end{array}$ & $\begin{array}{c}\text { Technology } \\
\text { Skill }\end{array}$ & $\begin{array}{c}\text { Self-Direct } \\
\text { Learning }\end{array}$ & Motivation \\
\hline Very Low & $\mathrm{X} \leq 10,05$ & $\mathrm{X} \leq 24$ & $\mathrm{X} \leq 28,5$ & $\mathrm{X} \leq 10,05$ \\
Low & $10,05<\mathrm{X} \leq 13,35$ & $24<\mathrm{X} \leq 32$ & $28,5<\mathrm{X} \leq 37,5$ & $10,05<\mathrm{X} \leq 13,35$ \\
Medium & $13,35<\mathrm{X} \leq 16,65$ & $32<\mathrm{X} \leq 40$ & $37,5<\mathrm{X} \leq 46,5$ & $13,35<\mathrm{X} \leq 16,65$ \\
High & $16,65<\mathrm{X} \leq 19,95$ & $40<\mathrm{X} \leq 48$ & $46,5<\mathrm{X} \leq 55,5$ & $16,65<\mathrm{X} \leq 19,95$ \\
Very High & $19,95<\mathrm{X}$ & $48<\mathrm{X}$ & $55,5<\mathrm{X}$ & $19,95<\mathrm{X}$ \\
\hline
\end{tabular}

\section{RESULT AND DISCUSSION}

\section{Result}

Based on the results of questionnaires that have been collected as many as 215 students, the data obtained are in the form of tables and percentage indicators. Then the effect of the variable X on Y. Based on descriptive statistics, the mean is 131.04 , the median is 132.00 , and the standard deviation is 18.39 , which is based on a questionnaire that has been filled out by elementary school teacher education students in Yogyakarta. Furthermore, to determine the TR ability of elementary teacher education students based on the percentage of results per indicator is presented. The TR indicator table can be seen in Table 4. 
Table 4. Mean Indicator Technology Readiness

\begin{tabular}{llll}
\hline Indicator & Mean & SD & Category \\
\hline Equipment Capability & 17,41 & 3,419 & High \\
Technology skill & 42,30 & 7,221 & High \\
Self-direct learning & 53,24 & 7,884 & Very High \\
Motivation & 18,10 & 3,210 & Very High \\
\hline
\end{tabular}

Based on Table 4. The analysis results show that the TR ability of school teacher education is in Yogyakarta mostly shows a very high category on self-learning and motivational indicators. However, most equipment capabilities and indicators of technical skills are still in the high-level category. It requires some strategies to improve this ability to be able to reach a very high level. Furthermore, a simple regression analysis is needed to determine how much influence TR has on perceived usefulness; The results showed that the calculated t value was 7,472 and the table was 2,234, so it can be assumed that there is a positive influence between TR on perceived usefulness, especially for elementary school teacher education students in Yogyakarta.

\section{Discussion}

The overall TR indicators are in the high-very high category; It is known from each indicator that each individual can accept the presence of new technology. In the indicator of equipment capability, it is known that the level of readiness in preparing the equipment has been reached, which means that several aspects such as sources of access either from computers or mobile phones, network access, and being able to utilize the basics of use have been adequately fulfilled. However, previous research has shown that students are confident to complete assignments regardless of their technological readiness (Sahin \& Yilmaz, 2020; Suni Astini, 2020; Warden et al., 2020). In the technological skills indicator, it can be perceived that individuals have mastered the skills to use technology to support the learning and learning process during the pandemic (Christopoulos \& Sprangers, 2021; Churiyah et al., 2020; Mpungose, 2021). This is reinforced by utilizing learning technology and skills that improve student preparation and increase targeted learning (Azhari \& Fajri, 2021; Khatoony \& Nezhadmehr, 2020). This means that students' mastery of skills in Yogyakarta has shown a high category (Kenny et al., 2020; Petko et al., 2018; Stone et al., 2020). In independent learning indicators, it can be felt that the indicator shows a very high category. It is essential to support the academic achievement of students. Direct self-learning is another characteristic personality factor closely related to academic achievement (Geng et al., 2019; Hanik, 2020; Zetriuslita et al., 2020). Empirical research gives a positive impression between independent learning and academic performance (Heo \& Toomey, 2020; Lin \& Wu, 2016; Rabgay, 2018). Several personality factors influence self-learning; A meta-analysis found that self-learning was positively correlated with intrinsic motivation, internal locus of control, academic achievement (Akbari \& Sahibzada, 2020; Haidari et al., 2019). This means that the independent learning ability of students in Yogyakarta is excellent. They can apply self-study, which is the primary basis for self-study, especially in learning new technologies.

The motivation indicator shows that students in Yogyakarta have shown a very high category. Based on the fact that individuals have three psychological needs: competence; autonomy; reciprocal relationships, all three to improve well-being and encourage doing something. Then it will consciously motivate students in preparing for the presence of new technology. This means that motivation indicators are essential indicators in supporting individuals in encouraging and preparing for the use of new technologies and improve results (Howard et al., 2016; Rafiee \& Abbasian-Naghneh, 2021). Furthermore, the average shows that all TR indicators are in the high category, which means that elementary school teacher education students in Yogyakarta can accept and believe that new technology will help improve performance and achievement according to what they want. It is felt that TR has a significant positive effect on perceived usefulness (H.-Y. Chang et al., 2021; Rafiee \& Abbasian-Naghneh, 2021). These results provide new reinforcement of the impact of covid-19, making students ready to prepare for the use of new technology; this is evidence to answer questions that have been made by (Alam \& Asimiran, 2021; Winter et al., 2021). His research explained that students during the pandemic had better performance than prepandemic students, so the role of technology will positively impact the role of future teacher candidates, making the teaching and learning process more enjoyable (Danniels et al., 2020; Raja \& Nagasubramani, 2018).

Based on the above, it can be assumed that a good TR awareness of each individual can help accept the presence of new technology and improve the individual's desired performance and work performance. This research is expected to provide recommendations to stakeholders about the impact of TR on behavior and achievement, inform potential shortcomings in its use, and enrich the literature on TR capabilities in Yogyakarta. However, this study has limitations; namely, the data collection method only uses a 
questionnaire, so that it cannot describe other perspectives in detail for each individual. So those further researchers are expected to use mixed methods or other types of research to answer the limitations of previous research. This research implies that educators or stakeholders should be aware of the importance of TR and the use of technology services by encouraging positive attitudes towards technology to reduce reluctance to use technology.

\section{CONCLUSION}

Technology readiness has a significant positive effect on perceived usefulness. The use of technology readiness in elementary school teacher education students had a positive impact on achieving the knowledge transfer process and researchers found no obstacles during the distance learning process. These results provide new reinforcement of the impact of covid-19, making students ready to prepare for the use of new technology.

\section{REFERENCES}

Abbasi, S., Ayoob, T., Malik, A., \& Memon, S. I. (2020). Perceptions of Students Regarding E-Learning during Covid-19 at a Private Medical College. Pak J Med Sci, 36. https://doi.org/10.12669\%2Fpjms.36.COVID19-S4.2766.

Aini, Q., Rahardja, U., \& Khoirunisa, A. (2020). Blockchain Technology into Gamification on Education. IJCCS (Indonesian Journal of Computing and Cybernetics Systems), 14(2). https://doi.org/10.22146/ijccs.53221.

Akbari, O., \& Sahibzada, J. (2020). Students' Self-Confidence and Its Impacts on Their Learning Process. American International Journal of Social Science Research, 5(1), 1-15. https://doi.org/10.46281/aijssr.v5i1.462.

Al-Hariri, M. T., \& Al-Hattami, A. A. (2017). Impact of students' use of technology on their learning achievements in physiology courses at the University of Dammam. Journal of Taibah University Medical Sciences, 12(1), 82-85. https://doi.org/10.1016/J.JTUMED.2016.07.004.

Alam, G. M., \& Asimiran, S. (2021). Online technology: Sustainable higher education or diploma disease for emerging society during emergency-comparison between pre and during COVID-19. $\begin{array}{lllll}\text { Technological Forecasting } & \text { Social } & \text { Change, }\end{array}$ https://doi.org/10.1016/j.techfore.2021.121034.

Azhari, B., \& Fajri, I. (2021). Distance learning during the COVID-19 pandemic: School closure in Indonesia. International Journal of Mathematical Education in Science and Technology. https://doi.org/10.1080/0020739X.2021.1875072.

Bakirtaş, H., \& Akkaş, C. (2020). Technology Readiness And Technology Acceptance Of Academic Staffs. International Journal of Management Economics and Business, 16(4). https://doi.org/10.17130/ijmeb.853629.

Blakely, M. L., McKnight, K. D., Darling, R. A., \& Moody, E. J. (2020). Using an OSCE to assess the potential for assistive technology to enhance communication between student pharmacists and simulated patients who are deaf/hard of hearing. Journal of the American Pharmacists Association, 60(6). https://doi.org/10.1016/j.japh.2020.08.031.

Bozkurt, A., Jung, I., Xiao, J., Vladimirschi, V., Schuwer, R., Egorov, G., Lambert, S. R., \& Al-Freih, M. (2020). A global outlook to the interruption of education due to COVID-19 Pandemic: Navigating in a time of uncertainty and crisis. Asian Journal of Distance Education, 15(1). https://doi.org/10.5281/zenodo.3878572No Title.

Burbules, N. C., Fan, G., \& Repp, P. (2020). Five trends of education and technology in a sustainable future. Geography and Sustainability, 1(2), 93-97. https://doi.org/10.1016/J.GEOSUS.2020.05.001.

Chang, H.-Y., Wu, H.-F., Chang, Y.-C., Tseng, Y.-S., \& Wang, Y.-C. (2021). The effects of a virtual simulationbased, mobile technology application on nursing students' learning achievement and cognitive load: Randomized controlled trial. International Journal of Nursing Studies, 120. https://doi.org/10.1016/j.ijnurstu.2021.103948.

Chang, Y.-Z., Yu, C.-W., Chao, C.-M., \& Lin, F.-C. (2020). Influences on medical app adoption by patients: the unified theory of acceptance and use of technology model and the moderating effects of technology readiness. The Social Science Journal. https://doi.org/10.1080/03623319.2020.1848338.

Christopoulos, A., \& Sprangers. (2021). Integration of educational technology during the Covid-19 pandemic: An analysis of teacher and student receptions. Cogent Education, 8(1). https://doi.org/10.1080/2331186X.2021.1964690.

Chung, N., Tyan, I., \& Han, H. (2017). Enhancing the smart tourism experience through geotag. Information 
Systems Frontiers, 19(4). https://doi.org/10.1007/s10796-016-9710-6.

Churiyah, M., Sholikhan, S., Filianti, F., \& Sakdiyyah, D. A. (2020). Indonesia Education Readiness Conducting Distance Learning in Covid-19 Pandemic Situation. International Journal of Multicultural and Multireligious Understanding, 7(6), 491. https://doi.org/10.18415/ijmmu.v7i6.1833.

Comi, S. L., Argentin, G., Gui, M., Origo, F., \& Pagani, L. (2017). Is it the way they use it? Teachers, ICT and student achievement. Economics of Education Review, 56. https://doi.org/10.1016/j.econedurev.2016.11.007.

Danniels, E., Pyle, A., \& DeLuca, C. (2020). The role of technology in supporting classroom assessment in play-based kindergarten. Teaching and Teacher Education, 88(1). https://doi.org/10.1016/j.tate.2019.102966.

Geng, S., Law, K. M. Y., \& Niu, B. (2019). Investigating self-directed learning and technology readiness in blending learning environment. International Journal of Educational Technology in Higher Education, 16(1), 17. https://doi.org/10.1186/s41239-019-0147-0.

Haidari, S. M., Yelken, T. Y., \& Akay, C. (2019). Technology-enhanced self-directed language learning behaviors of EFL student teachers. Contemporary Educational TechnologyEducational Technology. https://doi.org/10.30935/cet.590003.

Hanik, E. U. (2020). Self directed learning berbasis literasi digital pada masa pandemi covid-19 di Madrasah $\begin{array}{lllll}\text { Ibtidaiyah. ELEMENTARY: Islamic Teacher Journal, } & 83 .\end{array}$ https://doi.org/10.21043/elementary.v8i1.7417.

Heo, M., \& Toomey, N. (2020). Learning with multimedia: The effects of gender, type of multimedia learning resources, and spatial ability. Computers and Education, 146, 103747. https://doi.org/10.1016/j.compedu.2019.103747.

Hoareau, L., Thomas, A., Tazouti, Y., Dinet, J., Luxembourger, C., \& Jarlégan, A. (2021). Beliefs about digital technologies and teachers' acceptance of an educational app for preschoolers. Computers \& Education, 172. https://doi.org/10.1016/j.compedu.2021.104264.

Howard, S. K., Ma, J., \& Yang, J. (2016). Student rules: Exploring patterns of students' computer-efficacy and engagement with digital technologies in learning. Computers \& Education, 101. https://doi.org/10.1016/j.compedu.2016.05.008.

Kaushik, A. K., \& Rahman, Z. (2017). An empirical investigation of tourist's choice of service delivery options. International Journal of Contemporary Hospitality Management, 29(7). https://doi.org/10.1108/IJCHM-08-2015-0438.

Kenny, L.-A. T., Gaston, T., Powers, K., \& Isaac-Dockery, A. (2020). Anxiety in nursing students: The impact of using mobile technology with quick response codes. Nurse Education Today, 89. https://doi.org/10.1016/j.nedt.2020.104382.

Khatoony, S., \& Nezhadmehr, M. (2020). EFL Teachers ' Challenges in the Integration of Technology for Online Classrooms during Coronavirus ( COVID-19) Pandemic in Iran Shiva Khatoony. The Asian Journal of English Language \& Pedagogy, 8, 1-16.

Lau, E. Y. H., \& Lee, K. (2021). Parents' Views on Young Children's Distance Learning and Screen Time During COVID-19 Class Suspension in Hong Kong. Early Education and Development, 32(6), 863-880. https://doi.org/10.1080/10409289.2020.1843925.

Liao, S., Hong, J.-C., Wen, M.-H., Pan, Y.-C., \& Wu, Y.-. (2018). Applying Technology Acceptance Model (TAM) to explore Users' Behavioral Intention to Adopt a Performance Assessment System for E-book Production. EURASIA Journal of Mathematics, Science and Technology Education, 14(10). https://doi.org/10.29333/ejmste/93575.

Lin, C.-S., \& Wu, R. Y.-W. (2016). Effects of Web-Based Creative Thinking Teaching On Students' Creativity and Learning Outcome. EURASIA Journal of Mathematics, Science and Technology Education, 12(6). https://doi.org/10.12973/eurasia.2016.1558a.

Liu, J., \& Wang, Y. (2020). Research on experimental tourism teaching mode based on modern educational technology. Microprocessors and Microsystems. https://doi.org/10.1016/j.micpro.2020.103436.

MacLachlan, M., Banes, D., Bell, D., Borg, J., Donnelly, B., Fembek, M., Ghosh, R., Gowran, R. J., Hannay, E., Hiscock, D., Hoogerwerf, E. J., Howe, T., Kohler, F., Layton, N., Long, S., Mannan, H., Mji, G., Odera Ongolo, T., Perry, K., ... Hooks, H. (2018). Assistive technology policy: a position paper from the first global research, innovation, and education on assistive technology (GREAT) summit. Disability and Rehabilitation: Assistive Technology, 13(5), 454-466. https://doi.org/10.1080/17483107.2018.1468496.

Mali, D., \& Lim, H. (2021). How do students perceive face-to-face/blended learning as a result of the Covid19 pandemic? International Journal of Management Education, 19(3), 100552. https://doi.org/10.1016/j.ijme.2021.100552.

Martens, M., Roll, O., \& Elliott, R. (2017). Testing the Technology Readiness and Acceptance Model for Mobile 
Payments Across Germany and South Africa. International Journal of Innovation and Technology Management, 14(6). https://doi.org/10.1142/S021987701750033X.

Martínez-Gautier, D., Garrido-Yserte, R., \& Gallo-Rivera, M.-T. (2021). Educational performance and ICTs: Availability, use, misuse and context. Journal of Business Research, 135. https://doi.org/10.1016/j.jbusres.2021.06.027.

Mpungose, C. B. (2021). Lecturers' reflections on use of Zoom video conferencing technology for e-learning at a South African university in the context of coronavirus. African Identities. https: //doi.org/10.1080/14725843.2021.1902268.

Park, H. J., \& Zhang, Y. (2021). Technology readiness and technology paradox of unmanned convenience store users. Journal of Retailing and Consumer Services, 9. https://doi.org/10.1016/j.jretconser.2021.102523.

Petko, D., Prasse, D., \& Cantieni, A. (2018). The Interplay of School Readiness and Teacher Readiness for Educational Technology Integration: A Structural Equation Model. Computers in the Schools, 35(1). https: //doi.org/10.1080/07380569.2018.1428007.

Rabgay, T. (2018). The effect of using cooperative learning method on tenth grade students' learning achievement and attitude towards biology. International Journal of Instruction, 11(2), 265-280. https://doi.org/10.12973/iji.2018.11218a.

Rafiee, M., \& Abbasian-Naghneh, S. (2021). E-learning: development of a model to assess the acceptance and readiness of technology among language learners. Computer Assisted Language Learning, 34(6). https://doi.org/10.1080/09588221.2019.1640255.

Rahardja, Hidayanto, Hariguna, T., \& Aini, Q. (2019). Design Framework on Tertiary Education System in Indonesia Using Blockchain Technology. 2019 7th International Conference on Cyber and IT Service Management, 1(1). https://doi.org/10.1109/CITSM47753.2019.8965380.

Raja, R., \& Nagasubramani, P. C. (2018). Impact of modern technology in education. Journal of Applied and Advanced Research, 3(S1), 33. https://doi.org/10.21839/jaar.2018.v3is1.165.

Richardson, M., Gorley, M., Wang, Y., Aiello, G., Pintsuk, G., \& Gaganidze, E. (2021). Technology readiness assessment of materials for DEMO in-vessel applications. Journal of Nuclear Materials, 550. https://doi.org/10.1016/j.jnucmat.2021.152906.

Roy, S. K., Balaji, M. S., Sadeque, S., Nguyen, B., \& Melewar, T. C. (2017). Constituents and consequences of smart customer experience in retailing. Technological Forecasting and Social Change, 124. https: //doi.org/10.1016/j.techfore.2016.09.022.

Saddhono, K., Sudarsana, I. K., \& Iskandar, A. (2019). Implementation of Indonesian Language the learning Based on Information and Communication Technology in Improving Senior High School Students' Achievement in Surakarta. Journal of Physics: Conference Series, 1254(1). https://doi.org/10.1088/1742-6596/1254/1/012059.

Saha, A., Dutta, A., \& Sifat, R. I. (2021). The mental impact of digital divide due to COVID-19 pandemic induced emergency online learning at undergraduate level: Evidence from undergraduate students from Dhaka City. Journal of Affective Disorders, 294(June), 170-179. https://doi.org/10.1016/j.jad.2021.07.045.

Sahin, D., \& Yilmaz, R. M. (2020). The effect of Augmented Reality Technology on middle school students' achievements and attitudes towards science education. Computers \& Education, 144. https://doi.org/10.1016/j.compedu.2019.103710.

Shohel, M. M. C., \& Kirkwood, A. (2012). Using technology for enhancing teaching and learning in Bangladesh: Challenges and consequences. Learning, Media and Technology, 37(4), 414-428. https://doi.org/10.1080/17439884.2012.671177.

Stone, R., Cooke, M., \& Mitchell, M. (2020). Exploring the meaning of undergraduate nursing students' experiences and confidence in clinical skills using video. Nurse Education Today, 86. https://doi.org/10.1016/j.nedt.2019.104322.

Summak, M. S., Bağlibel, M., \& Samancioğlu, M. (2010). Technology readiness of primary school teachers: A case study in Turkey. Procedia - Social and Behavioral Sciences, 2(2), 2671-2675. https://doi.org/10.1016/J.SBSPR0.2010.03.393.

Sun, S., Lee, P. C., Law, R., \& Hyun, S. S. (2020). An investigation of the moderating effects of current job position level and hotel work experience between technology readiness and technology acceptance. International Journal of Hospitality Management, 90. https://doi.org/10.1016/j.ijhm.2020.102633.

Suni Astini, N. K. (2020). Tantangan Dan Peluang Pemanfaatan Teknologi Informasi Dalam Pembelajaran Online Masa Covid-19. Cetta: Jurnal Ilmu Pendidikan, 3(2), 241-255. https://doi.org/10.37329/cetta.v3i2.452.

Tuma, F. (2021). The use of educational technology for interactive teaching in lectures. Annals of Medicine and Surgery 62, 231-235. https://doi.org/10.1016/j.amsu.2021.01.051. 
Unwin, T. (2019). The Future Use of Technology in Education and Learning in the Commonwealth. The Round Table, 108(4). https://doi.org/10.1080/00358533.2019.1634891.

Warden, C. A., Yi-Shun, W., Stanworth, J. O., \& Chen, J. F. (2020). Millennials' technology readiness and selfefficacy in online classes. Innovations in Education and Teaching International. https://doi.org/10.1080/14703297.2020.1798269.

Weng, S. S., \& Chen, H. C. (2020). Exploring the role of deep learning technology in the sustainable development of the music production industry. Sustainability (Switzerland), 12(2), 1-20. https: //doi.org/10.3390/su12020625.

Winter, E., Costello, A., O’Brien, M., \& Hickey, G. (2021). Teachers' use of technology and the impact of Covid19. Irish Educational Studies, 40(2). https://doi.org/10.1080/03323315.2021.1916559.

Yilmaz, R. M., \& Goktas, Y. (2017). Using augmented reality technology in storytelling activities: examining elementary students' narrative skill and creativity. Virtual Reality, 21. https://doi.org/10.1007/s10055-016-0300-1.

Zetriuslita, Nofriyandi, \& Istikomah, E. (2020). The Increasing Self-Efficacy and Self-Regulated through GeoGebra Based Teaching reviewed from Initial Mathematical Ability (IMA) Level. International Journal of Instruction, 14(1), 587-598. https://doi.org/10.29333/IJI.2021.14135A.

Zhu, X., \& Luo, S. (2021). The influence of computer network technology on national income distribution under the background of social economy. Computer Communications, 177. https://doi.org/10.1016/j.comcom.2021.06.025. 